\title{
Monolingual and Bilingual Learners' Dictionaries*
}

\author{
Rufus H. Gouws, Department of Afrikaans and Dutch, University of \\ Stellenbosch, Stellenbosch, Republic of South Africa (rhg@sun.ac.za)
}

\begin{abstract}
When deciding on the best learners' dictionary for a specific user and a specific situation of usage one often has to make a choice between a monolingual and a bilingual learners' dictionary. This article discusses some aspects of the user-driven approach so prevalent in modernday lexicographic thought, focuses broadly on dictionary typology and takes a closer look at monolingual and bilingual learners' dictionaries. Some problems users experience when learning a new language, e.g. language distortion and problems related to the phenomenon of false friends, especially in closely related languages, are mentioned. It is indicated that a typological hybrid dictionary could assist certain users. The importance of an unambiguous identification of the relevant lexicographic functions is emphasised and the notions of function condensation and function merging are introduced. It is shown that the typological choice should be determined by a function-based approach to dictionary usage.
\end{abstract}

Keywords: BILINGUAL DICTIONARY, FALSE FRIENDS, FUNCTION CONDENSATION, FUNCTION MERGING, GENUINE PURPOSE, LEARNERS' DICTIONARY, LEXICOGRAPHIC FUNCTIONS, MONOLINGUAL DICTIONARY, TEXT PRODUCTION, TEXT RECEPTION, TYPOLOGICAL HYBRID, TYPOLOGY.

Opsomming: Eentalige en tweetalige aanleerderwoordeboeke. Wanneer besluit moet word oor die beste aanleerderwoordeboek vir 'n spesifieke gebruiker en 'n spesifieke gebruiksituasie moet daar dikwels gekies word tussen 'n eentalige en 'n tweetalige aanleerderwoordeboek. Hierdie artikel bespreek bepaalde aspekte van die gebruikersgedrewe benadering wat kenmerkend is van die moderne leksikografiese denke, fokus breedweg op woordeboektipologie en gee in meer besonderhede aandag aan sekere aspekte van eentalige en tweetalige aanleerderwoordeboeke. Bepaalde probleme wat gebruikers ervaar by die aanleer van 'n vreemde taal, bv. taalversteuring en probleme verwant aan die verskynsel van valse vriende, veral in nou verwante tale, kry aandag. Daar word aangedui dat 'n tipologiese hibriede woordeboek van waarde kan wees vir sekere gebruikers. Die belang van 'n ondubbelsinnige vasstelling van die tersaaklike woordeboekfunksies word beklemtoon en die begrippe funksieverdigting en funksiesamesmelting word aan die orde gestel. Daar word aangetoon dat die tipologiese keuse bepaal moet word deur 'n funksie-gebaseerde benadering tot woordeboekgebruik.

Sleutelwoorde: AANLEERDERWOORDEBOEK, EENTALIGE WOORDEBOEK, FUNKSIE-

* This article was read as a paper at the Seminar on Learners' Dictionaries presented by the African Association for Lexicography at the University of Pretoria, Pretoria, Republic of South Africa, 11-12 November 2002.

Lexikos 14 (AFRILEX-reeks/series 2004: 14): 264-274 
SAMESMELTING, FUNKSIEVERDIGTING, LEKSIKOGRAFIESE FUNKSIES, TEKSPRODUKSIE, TEKSRESEPSIE, TIPOLOGIE, TIPOLOGIESE HIBRIED, TWEETALIGE WOORDEBOEK, VALSE VRIENDE, WERKLIKE DOEL

\section{Introduction}

There is nothing as practical as a good theory. Theoretical lexicography may never be regarded as theory merely for the sake of theory. In metalexicography theoretical deliberations should always endeavour to enhance the quality of the lexicographic practice. The lexicographic practice is performed by means of dictionaries. Consequently dictionaries have to be regarded as practical tools in the hand of the language user. As practical tools dictionaries should be devised in such a way that a well-identified user can retrieve the kind of information needed for a specific purpose. This implies that dictionaries should be seen as utility instruments, to be used by the ordinary member of a speech community. A dictionary has to reflect the real language as it is encountered in daily communication and not the language which purists would necessarily regard as the preferred form.

In order to be functional instruments, dictionaries have to fulfil a specific purpose. The identification and formulation of this purpose has to precede the compilation process because the compilation process has to be steered by the purpose of the specific dictionary project. In metalexicographical terms this purpose of a dictionary is known as the genuine purpose (cf. Wiegand 1998). According to Wiegand, the genuine purpose of a dictionary is that it should be used for the retrieval of information from lexicographic data regarding those linguistic expressions included for treatment in the specific dictionary.

Tarp (2000: 198) directs his description of the genuine purpose of a dictionary at a concrete product which has to be used in specific circumstances to solve specific problems:

The dictionary covers this or that area and is conceived to assist users with these or those characteristics in this or that situation in order to solve problems of this or that sort.

Taking the cue from Wiegand (1998), Gouws (2001) defines the genuine purpose of a dictionary as follows:

The genuine purpose of a dictionary implies that a dictionary is produced so that the target user who uses the dictionary in a typical usage context will have an instrument to assist him in achieving a successful dictionary consultation procedure by reaching the goals that motivated the search. The genuine purpose of a dictionary should therefore be to ensure successful dictionary consultation procedures. A successful dictionary consultation procedure depends on the way in which the needed linguistic information can be retrieved.

The last number of years have witnessed the emergence of a user-driven approach in lexicography. This is made clear by Hartmann $(1989: 103,104)$ when he says: 
"An analysis of users' needs should precede dictionary design" and "The design of any dictionary cannot be considered realistic unless it takes into account the likely needs of various users in various situations." Besides the emergence of a focus on the user an awareness of dictionary functions has also increased. Wiegand (2001: 217) welcomes the fact that the latest dictionary research pays so much attention to dictionary functions. It can rightfully be argued that the compilation of any dictionary should not only be preceded by a clear identification of the intended target user, the needs and the reference skills of the target user and the user and usage situation of the target user but also by an unambiguous decision regarding the functions of the planned dictionary.

When determining the functions of a dictionary and the way in which the lexicographic treatment will ensure that the needed functions prevail the lexicographer needs to be familiar with the intended user of the dictionary. Tarp (2000: 194) indicates the importance of this knowledge regarding the characteristics of the target users of a dictionary. These characteristics include their language competence, i.e. which language is their mother tongue, at what level they have mastered their mother tongue and at what level they have mastered the foreign language. When speaking about the user needs Tarp (2000: 195-196) says that a user might need among others

- information about the native language,

- information about a foreign language,

- a comparison between the native and a foreign language, and

- information about culture and the world in general.

This is not only true of general monolingual and/or bilingual dictionaries but also of learners' dictionaries and should lead to a choice by the lexicographer regarding the functions of the intended dictionary. A dictionary can be monofunctional, bifunctional or polyfunctional. Economic and pragmatic reasons have led to a situation where the publication of dictionaries is often not determined by the needs of the users but by the financial situation of the publishing house. Consequently lexicographers often have to embark on procedures of function merging or even function condensation because more than one function has to prevail in a given dictionary. In many cases this can only be possible if the dictionary does not give a full realisation of a given function but allows it in a condensed way.

\section{Dictionary typology}

The needs of the user do not only influence the contents and the structure of a dictionary but the typological classification of a dictionary should also be a direct result of the needs in a specific speech community. When dealing with dictionary typology one should be careful that the nature and extent of traditional typological categories do not impede the successful implementation of 
user-determined functions. To illustrate this: working only with a broad and general typological category like bilingual dictionary says very little about the needs of e.g. primary school learners or professional translators. Neither does it say anything about text reception or text production or about native or foreign language users. A mere typological classification like monolingual dictionary or bilingual dictionary is actually a very blunt instrument which has a limited value when it comes to the functions of the dictionary.

Working with typological classifications one should negotiate the fact that many typological categories need a thorough subclassification to ensure a proper and valid data presentation and distribution in terms of the real needs of real users. However, parallel to the notions of function merging and function condensation run the notions of typological merging and typological condensation. One of the implications of these notions is the obliteration of subtypological categories in favour of broad and general typological categories, the socalled "superheroes" of dictionary typology. In the field of dictionary typology the term typological hybrid is used to indicate a dictionary which displays features from more than one typological category, e.g. a monolingual descriptive dictionary with a translation equivalent included in the comment on semantics of each article. The term typological hybrid could actually also be applied to the typological superheroes because they display features from various typological categories. In a speech community with a less-developed dictionary collection, it is more likely than not that one would find superheroes representing what should ideally be represented by a range of smaller dictionaries belonging to a variety of subtypological categories.

Learners' dictionaries represent one typological category which tends towards superhero status on account of the diverse nature of the data included in learners' dictionaries and on account of the wide spectrum of the user groups at which learners' dictionaries are directed. When one looks at dictionaries displaying the typical functions of learners' dictionaries it is evident that two distinct user groups can be determined, i.e. learners using the dictionary in a school environment and learners not involved with formal school activities. In his classification of dictionaries, Gouws (2001: 74) uses the category pedagogical dictionaries to include both learners' and school dictionaries. There it is argued that school dictionaries are primarily for mother-tongue speakers learning their own language whereas learners' dictionaries are for studying a foreign language. Pedagogical dictionaries is also a superhero term and not a very apt term because it does not really present a distinctive and specific lexicographic category due to the fact that the majority of dictionaries do have a pedagogic assignment in terms of e.g. their knowledge- and their communication-directed functions.

The term school dictionary is also not a very apt designation - it has the nature of a mini-superhero. So many different dictionaries could be classified under this term, including picture dictionaries for pre-primary use, monolingual and bilingual dictionaries for the different school phases as well as lan- 
guage for special purpose dictionaries dealing with the terminology of school subjects. All of these dictionaries display certain features typically relevant to learners' dictionaries.

The term learners' dictionary should rather be used as an umbrella term for both school- and non-school-directed dictionaries which display typical learners' features.

It is important to look at the primary use of a learners' dictionary. In a school situation, it could be used by the teacher as an teaching instrument or by the learner as a learning instrument. In German, a distinction is made between Lehrwörterbücher (teaching dictionaries) and Lernwörterbücher (learning dictionaries). When discussing learners' dictionaries one should also make provision for these two features which are relevant to this dictionary type.

For the present discussion learners' dictionary will be used as a superhero term but the emphasis will be on a subclassification within this broad category. Although the traditional terms bilingual and monolingual will be used in this subclassification it will also be indicated that these terms are often misused and frequently fail to convey the real nature of a specific dictionary.

\section{Monolingual or bilingual}

Before referring to learners' dictionaries, one must have a clear and unambiguous understanding of the terms bilingual dictionary and monolingual dictionary. One of the first Afrikaans dictionaries, the Proeve van een Kaapsch Hollandsch Idioticon (Mansvelt 1884) was published to give an account of the differences between early Afrikaans and Dutch. The dictionary endeavoured to convince a Dutch user group that Afrikaans had developed as a fully-fledged language. The outer texts of this dictionary are in Dutch and the central list displays an Afrikaans macrostructure but the treatment is in Dutch, e.g.

1. penwortel, ... de hoofdwortel van sommige boomen, die loodrecht naar beneden gaat.

The treatment allocated to this lemma is the typical treatment to be found in a monolingual descriptive dictionary. One language is presented as the source language and the treatment is directed at that language although the treatment is done in another language. Is this a monolingual or a bilingual dictionary? It is a monolingual dictionary.

The occurrence of translation equivalents in the comment on semantics of a dictionary article does not necessarily elevate that dictionary to the level of being classified as bilingual; cf. the following examples from Nuwe woordeboek sonder grense:

2. aanval awerkwoord (het aangeval)

Dit beteken om iemand of iets seer te maak of skade aan te doen.

$\rightarrow$ Ons gaan die vyand met knopkieries en skilde aanval [attack]. 
$\rightarrow$ My vriendin is deur ' $n$ hond aangeval [attack]; gevolglik moes sy hospitaal toe gaan. $\rightarrow$ Diere soos ape val mense in motors aan [attack] omdat hulle kos wil hê.

naamwoord (aanvalle, aanvalletjie)

'n Aanval is die aksie om iemand of iets seer te maak of skade aan te doen.

$\rightarrow$ Tydens die aanval [the attack] is baie geboue en huise verwoes.

$\rightarrow$ In ' $n$ aanval [an attack] op die bank is vyf wagte gewond.

\section{3. aar naamwoord (are, aartjie)}

( 'n Aar is die pypie waardeur bloed na die hart vervoer word.

$\rightarrow$ Die dokter het die inspuitnaald in ' $n$ aar [vein] in my arm gedruk.

2 Dit is die deel van byvoorbeeld die koringplant waaraan die korrels vas is.

$\rightarrow$ Tydens die oesseisoen word die are van die koring [ears of corn] gepluk.

This is a dictionary compiled for a specified group of primary school learners with Afrikaans as third or fourth language, to be used in their Afrikaans curriculum. The dictionary should give them an indication of the meaning of a limited number of Afrikaans words relevant to their learning endeavour of Afrikaans as a foreign language. Although the target users of this dictionary primarily have to use this dictionary in their learning of Afrikaans their command of English is most probably better than their command of Afrikaans. Important from a lexicographic perspective is that they get access to the lemma sign representing the Afrikaans word they have encountered in their texts. This can be done by means of the alphabetically ordered macrostructure of the dictionary. However, it is just as important that they get access to an Afrikaans equivalent needed to produce a text in Afrikaans. If they do not know the Afrikaans word the explanation of meaning is of little relevance to them and there is no way they will find the needed word if they cannot do it via a language with which they are more familiar. Consequently the dictionary plan makes provision for access via an alphabetically arranged English equivalent list presented as a back matter text. These equivalents are also given as entries in the comment on semantics of each article. Notwithstanding these English equivalents and the alphabetical equivalent register presented as a back matter text, this dictionary remains a monolingual dictionary - although in the words of Tarp a monolingual dictionary "with a bilingual dimension."

There are different interpretations of the terms monolingual dictionary and bilingual dictionary. When a distinction is made between monolingual and bilingual learners' dictionaries the reference to monolingual dictionaries typically bears on dictionaries where the source language items are treated in the source language. The source language treatment primarily focuses on a paraphrase of meaning and the presentation of cotext entries to illustrate the typical use as well as the syntactic features of the treatment unit. Bilingual learners' dictionaries are typically seen as dictionaries in which lexical items from two given partner languages are co-ordinated. The source language provides the lemmata or primary treatment units whereas the target language provides the translation equivalents. 


\section{What choices should the user have?}

\section{The availability of learners' dictionaries}

It is a well-known fact that the planning of a learners' dictionary has to be preceded by a clear identification of the intended target user of that dictionary. This identification of the target user does not only imply a knowledge of the level of language proficiency or the data types needed by the user but also a knowledge on the side of the lexicographer with regard to the mother-tongue of the target user. Bilingual learners' dictionaries are earmarked for a specific language pair whereas monolingual dictionaries, specifically those without a bilingual dimension, are directed at a more general target user group interested in learning a given foreign language.

\section{Some problems in this regard}

Learning a new language confronts learners not only with the lexicon and the grammar of that language but learners constantly have to negotiate their knowledge of their mother tongue and that of other languages familiar to them. In the process of learning a new language, language distortion is a real issue. A speaker of Zulu who wants to learn Chinese will experience little influence of language distortion. Because these two languages are vastly different the Zulu learner of Chinese will not be tempted to convey the structures of Zulu to Chinese. But when a Zulu speaker wants to learn another Nguni language, e.g. Xhosa, the target language will easily be influenced by his/her knowledge of the mother tongue. Closely related languages display a much stronger occurrence of language distortion.

German and Afrikaans are related languages. German has a word durchbringen and its Afrikaans equivalent is deurbring. As is the case with the German word durchbringen the Afrikaans word deurbring is also a polysemous lexical item. These words share senses like "to get something through" and "to waste money". The Afrikaans word deurbring is also used where German would use verbringen: die vakansie deurbring "to spend the holiday". The German-Afrikaans word list of a bilingual dictionary treating these two languages will present the Afrikaans word deurbring as a translation equivalent of the German lemma sign durchbringen. This would not be an incorrect equivalent but although they share some senses the Afrikaans form has a wider polysemous range and the lexicographer may not rely on the intuition of the dictionary user to know the differences. For all the senses of the lexical item represented by the lemma sign durchbringen the Afrikaans form deurbring could probably be used as an equivalent. A mere co-ordination of the forms durchbringen and deurbring will be of little assistance for the user in terms of needing to be familiar not only with the similarities between the source and target language forms but also with the differences. A listing of illustrative examples may help to indicate 
the mutual senses and usage situations but merely omitting an example illustrating a specific sense of the target language form represented by the translation equivalent which does not form part of the polysemous paradigm of the source language item represented by the lemma sign can be regarded as too implicit a way of conveying the more restricted polysemous range of the source language form. Users do not consult the entries in the search zone allocated to illustrative examples to ascertain the polysemous spectrum of a given source language form. Consequently it is very important that the comment on semantics of the article of a lemma sign like the German durchbringen should be divided into a subcomment on semantics for each of the senses of this lexical item - even if it implies the repetition of the same target language form as translation equivalent in each subcomment on semantics.

A monolingual German learners' dictionary not directed at target users from a specific speech community will not focus on the problems regarding durchbringen and deurbring. A dictionary aimed at speakers of Afrikaans who need to learn German will have to focus on this issue. When planning and using a monolingual learners' dictionary one has to ascertain whether the lexicographer has compiled the dictionary with a specific language group in mind because it is bound to influence the presentation and treatment of the dictionary.

Closely related languages also confront the lexicographer with problems with regard to partial false friends.

From a lexicographic perspective false friends do not really pose much of a problem for the lexicographer. A bigger problem is posed by partial false friends, i.e. the occurrence of formal identity or close identity and on a semantic level there is a relation although not one of identity but rather of relatedness. German and Afrikaans have the words die See/see and das Meer/meer. The German die See has the Afrikaans meer as translation equivalent and the German das Meer has the Afrikaans form see as translation equivalent. Both Dutch and Afrikaans have the adverb amper but they have direct opposite meanings: the Dutch amper means "almost not" whereas the Afrikaans amper means "almost'. The fact that these lexical pairs can often occur in similar usage environments adds to the confusion potential they have for the user. However, within the comment on semantics the translation equivalents should give enough guidance to make the user aware of these pitfalls.

The relevant issues to be accounted for by the data exposure structure in a bilingual dictionary dealing with closely related languages are not always on the level of the entries participating in the lemmatic addressing procedures but often resides in the combinatory possibilities of the word represented by the lemma sign or the translation equivalent. In the treatment of the Dutch lemma sign postzegel (postage stamp) the Afrikaans translation equivalent posseël should occur as one of the microstructural entries. This lemma and translation equivalent display systematic similarities and this pattern continues in combinations like postzegels verzamelen $\mathrm{x}$ posseëls versamel (to collect postage stamps). 
A typical usage of the Dutch word is in a combination like the following: een postzegel op een brief doen (to put a stamp on a letter). This is not translated into Afrikaans as ' $n$ posseël op ' $n$ brief doen but as ' $n$ posseël op ' $n$ brief plak. For the user of a Dutch-Afrikaans dictionary this difference is relevant and the dictionary should give account of it. The lemma and the translation equivalent(s) occur in a position of salience in an article. In a dictionary dealing with two closely related languages, the entries which could assist the user with real usage problems are often not the lemma and the translation equivalent(s) and are therefore not presented in that position of salience. Data exposure procedures are needed to draw the focus to these entries (cf. Gouws Forthcoming).

A bilingual dictionary should concentrate on those aspects that are contrastively relevant to the intended target user.

In the treatment of closely related languages, a lexicographer should be aware of the varied functions of the dictionary and the fact that the typical user could have different needs compared to the user of a bilingual dictionary dealing with unrelated languages. The emphasis in articles should not only be on procedures of lemmatic addressing but rather on the treatment of source language usage. In the article of a lemma sign like the Dutch postzegel, the lemma and the translation equivalent do have a role to play - in many usage situations the translation equivalent will primarily be looked up to confirm the proper form, and confirmation of a given form is a real part of text reception (cf. Gouws and Tarp 2004). However, the typical user will benefit more from the inclusion of the Dutch phrase een postzegel op een brief doen (to put a stamp on a letter) and its Afrikaans translation ' $n$ posseël op ' $n$ brief plak. The presentation of illustrative material should not only be carefully selected but the lexicographer should employ the data exposure structure of the dictionary to make the user aware of relevant contrasting forms or, where applicable, of the relevant similarities. Similarities could be treated as unmarked entries but contrasting forms should be allocated an additional entry to expose the nature of this data.

\section{Typological variations}

In a language with a spectrum of dictionary types and a variety of learners' dictionaries, the user in need of a learners' dictionary typically has to decide whether he/she needs a monolingual or a bilingual dictionary. It has been indicated (cf. Ilson 1985), that many language learners opt for a bilingual dictionary in which their mother-tongue is co-ordinated with the target language. The dictionary consultation process is then either to find a word in the foreign language for a given item in the mother tongue or to find the proper word in the mother tongue for a word encountered in the foreign language.

From a language didactic perspective it has been argued that it is better for the user to consult a monolingual dictionary because having to go through the paraphrase of meaning and the example sentences in the foreign language will 
assist the user to become more familiar with the foreign language. Once again it is important to take cognisance of the level of language proficiency of the intended target user. If the user is someone reasonably familiar with the foreign language the use of a monolingual dictionary could be an ideal solution. If a learner of say Sepedi is confronted with the Sepedi word reka he should consult a monolingual Sepedi learners' dictionary to find the lemma sign reka and the paraphrase of meaning in which the word is defined in Sepedi. If that learner already has the ability to understand the definition given in the monolingual dictionary then he/she can benefit from the monolingual dictionary by finding not only the meaning of the word but also some additional assistance. From a didactic perspective it may be true that the user will benefit more from a foreign language monolingual dictionary but from a user's perspective it is not always necessarily the case. Quite often one could argue in favour of the contrary. Once again the typical target user of the dictionary plays an important role.

If an adult English-speaking learner of Sepedi is confronted with the word reka the main purpose of his/her dictionary consultation process will not be to retrieve information regarding the activity to which the word reka refers. Although a definition of the word will be beneficial in terms of being confronted with a well-formed Sepedi sentence this may not be what the user really needs. The user may be familiar with the concept "to buy" but unfamiliar with the fact that reka is the Sepedi equivalent of the English verb to buy. Using the SepediEnglish component of a bilingual dictionary with English and Sepedi as partner languages may result in a much more rapid comprehension of the Sepedi word by having it co-ordinated with the English equivalent to buy.

The examples from Nuwe woordeboek sonder grense illustrate a similar aspect. The non-Afrikaans user of this dictionary may be familiar with the English word vein as well as with the meaning and use of this word. However, the person is not familiar with its Afrikaans equivalent aar. This user needs a dictionary giving him/her access to the Afrikaans form but it has to go via the English form. A monoaccessible Afrikaans descriptive learners' dictionary will be to little avail in such an endeavour.

Yet another possibility exists for users with a certain level of language proficiency. The lexicographer may decide to compile an explanatory dictionary with the lemma list in the foreign language but the explanations of meaning given in the mother tongue of the intended target user.

\section{Typology versus functions}

From the above-mentioned issues it should be clear that both monolingual and bilingual dictionaries could be used for different functions. Looking at the type of dictionary needed for a specific consultation procedure the focus should not be on bilingual or monolingual but rather on text production or text reception. We need a much stronger function-based dictionary classification. 


\section{In conclusion}

Existing methods of dictionary classification do not always reflect the role of that dictionary or the ways in which it can assist users. General and blunt typological classifications should be avoided in favour of a stronger functionbased approach.

\section{Bibliography}

Gouws, R.H. 2001. Lexicographic Training: Approaches and Topics. Emejulu, James Duplessis. (Ed.). 2001. Éléments de lexicographie gabonaise. Tome I: 58-94. New York: Jimnacs-Hillman.

Gouws, R.H. 2002. Equivalent Relations, Context and Cotext in Bilingual Dictionaries. Hermes, Journal of Linguistics 28: 195-209.

Gouws, R.H. Forthcoming. Issues Regarding the Comment on Semantics in Bilingual Dictionaries Dealing with Closely Related Languages. Petkov, P. (Ed.). Forthcoming Proceedings: Internationales Kolloquium zur Wörterbuchforschung.

Gouws, R.H., M. Stark and L. Gouws. 2004. Nuwe woordeboek sonder grense. Cape Town: Maskew Miller Longman.

Gouws, R.H. and S. Tarp. 2004. Wie leer wat uit Afrikaanse (aan)leerderwoordeboeke. Tydskrif vir Geesteswetenskappe.

Hartmann, R.R.K. 1989. Sociology of the Dictionary User: Hypothesis and Empirical Studies. Hausmann, F.J. et al. (Eds.). 1989-1991. Wörterbücher. Ein internationales Handbuch zur Lexikographie/Dictionaries. An International Encyclopedia of Lexicography/Dictionnaires. Encyclopédie internationale de lexicographie: 102-111. Berlin: De Gruyter.

Ilson, Robert (Ed.). 1985. Dictionaries, Lexicography and Language Learning. Oxford: Pergamon Press.

Mansvelt, N. 1884. Proeve van een Kaapsch-Hollandsch Idioticon. Cape Town: Van de Sandt de Villiers.

Tarp, S. 2000. Theoretical Challenges to LSP Lexicography. Lexikos 10: 189-208.

Wiegand, H.E. 1998. Wörterbuchforschung. Untersuchungen zur Wörterbuchbenutzung, zur Theorie, Geschichte, Kritik und Automatisierung der Lexikographie. 1. Teilband. Berlin/New York: De Gruyter.

Wiegand, H.E. 2001. Was eigentlich sind Wörterbuchfunktionen? Kritische Anmerkungen zur neueren und neusten Wörterbuchforschung. Lexicographica 17: 217-248. 